\title{
Yrkesfaglærerens paradoks: Utdanne til fagarbeid eller videre studier?
}

\author{
(The vocational teacher's paradox: \\ Educate for professional work or further studies?) \\ Else Marie Johansen \\ OsloMet - Storbyuniversitetet, Norge (ejohanse@oslomet.no)
}

\begin{abstract}
This article refers to the vocational teachers' reflections from experiences with students on the upper-secondary level health-care worker studies in Norway, who have a different purpose and basis for their education than to train as health-care workers.

The study is based on six group interviews with 15 vocational teachers at health-care worker studies and draws attention to the experiences and assessments that the teacher makes in educating health-care students. Knowledge of motivation, self-efficacy, and community of practice form the theoretical foundation for the study.

The results show that it is a complex group of students the teachers present in their reflections. Among other things, the teachers describe students who to a large extent do not know what they want with the education, as well as students who during the school year encounter practice and become insecure about their educational choices. The teachers therefore tend to facilitate a somewhat more general presentation of the subject, in order to embrace all the students' different bases and goals of the education. At the same time, teachers clearly stated that they set clear academic requirements for the students and requirements for active participation, but if the academic focus is general and not specifically aimed for the health-care worker, it may strengthen the understanding that the profession is less important.
\end{abstract}

Keywords: health-care workers studies, vocational teacher, motivation, self-efficacy, community of practice 
Yrkesfaglærerens paradoks: Utdanne til fagarbeid eller videre studier?

\section{Innledning}

For ungdom som vil utdanne seg til helsefagarbeider i Norge, er vanlig løp å velge utdanningsprogram for helse- og oppvekstfag innenfor yrkesfaglig videregående opplæring. De går da to år i skole, hvor det første året (Vg1) er generelt og dekker flere fag innenfor helse- og oppvekstsektoren. Det andre året (Vg2) er spesialisering til helsearbeiderfaget. Etter de to årene i videregående skole begynner de som lærlinger i en bedrift i ytterligere to år (Vg3). Dette er den såkalte læretiden. De tar så fagbrev og får formell yrkesfaglig kompetanse med tittelen helsefagarbeider og med autorisasjon som helsepersonell. Autorisasjonen gir dem en beskyttet tittel. Det er også en mulighet for elevene etter de to årene i videregående skole å velge å ta et såkalt påbygningsår $(\mathrm{Vg} 3)$ i skole, noe som gir generell studiekompetanse og dermed kvalifiserer til høyere utdanning.

Andelen elever som søker seg over til studieforberedende kurs etter å ha fullført skoledelen av opplæringen til helsefagarbeider (Vg2) er høy, og mange elever fullfører dermed ikke yrkesutdanningen de har startet på (NOU 2019:25, s. 92). Utfordringen med elever som underveis velger bort yrkeskompetanse som helsefagarbeider blir i tidligere forskning (se blant annet Skålholt et al., 2013, s. 91) i all hovedsak tilskrevet sider ved arbeidslivet, og dermed fastslås det at endringene må komme i arbeidslivet. En endring som kan gjøre yrket mer attraktivt for unge, er blant annet større tilgang på heltidsstillinger (Skålholt et al., 2013, s. 88; Statistisk sentralbyrå, 2019b, s. 7; Vabø et al., 2019, s. 15).

Denne artikkelen belyser yrkesfaglærernes erkjennelser knyttet til utdanning av elever til helsearbeiderfaget, nærmere bestemt: Hvilke refleksjoner har yrkesfaglærerne knyttet til utdanning av elever som har et annet formål og grunnlag for sin utdanning enn å kvalifisere seg til helsefagarbeider?

Artikkelen søker å kunne tilføre kunnskap om det dilemmaet som muligheten for påbygging til generell studiekompetanse, spesielt i en norsk kontekst, medfører for yrkesfaglæreren, samt hva det kan føre til av utfordringer i den yrkesfaglige opplæringen. Det er elevenes anledning til å kunne gjøre omvalg underveis i utdanningene som studeres ut fra yrkesfaglærerens oppfatninger om sitt arbeid med utdanning av elever som har et annet mål og grunnlag for sin utdanning enn å bli helsefagarbeidere.

Opplæringen til helsearbeiderfaget foregår på to ulike arenaer, både for elevene og for lærerne, siden elevene i yrkesfagopplæringen på andre trinn (Vg2) har en betydelig del, 253 timer/26 prosent (Utdanningsdirektoratet, 2020), av opplæringen ute i bedrifter i faget yrkesfaglig fordypning (YFF). Yrkesfaglig fordypning ble ved innføring av Kunnskapsløftet i 2006 opprettet som et forebyggende tiltak mot feilvalg og frafall i yrkesfaglig videregående skole (Sandal \& Smith, 2012, s. 2). YFF skal "bidra til å introdusere elevene for arbeidslivet, og gi regionalt og lokalt arbeidsliv mulighet til å definere innholdet i opplæringen" (Utdanningsdirektoratet, 2016, avsn. 2). Dette er med på å gjøre yrkesfaglærerens 
arbeid til en integrert del av videregående opplæring, men også forskjellig fra annet skolearbeid med disiplinbaserte fag (Tarrou \& Johannesen, 2010, s. 95).

Utdanningen til helsefagarbeider har en dobbel utfordring (Høst \& Larsen, 2018, s. 128). På den ene siden skal den utdanne helsefagarbeidere, på den andre skal den også legge til rette for at elevene skal kunne søke seg over til høyere utdanning. Dette er ifølge Høst og Larsen (2018) nødvendig for å øke statusen til utdanningen. Dermed kvalifiserer ikke utdanningen til helsearbeiderfaget bare til yrket helsefagarbeider, men læreren forbereder og motiverer også elevene til høyere utdanning (Høst \& Larsen, 2018, s. 128). Imidlertid slår Liedutvalget fast i NOU 2019:25 (s. 91) at hovedformålet med de yrkesfaglige utdanningsprogrammene skal være å utdanne fagarbeidere, og kaller det en svakhet at en stor andel av elevene velger seg over fra yrkesfag til studieforberedende kurs (NOU 2019:25, s. 92). Med bakgrunn i elevenes ønske om en overgang til høyere utdanning, har de i Finland mulighet til å søke opptak, enten direkte etter å ha fullført yrkesutdanning eller etter å ha jobbet i yrket noen år (Niittylahti et al., 2019, s. 34). I Norge har det siden 1970-tallet blitt undersøkt mulige løsninger til endringer i opplæringen som kan gi elevene de samme mulighetene som i Finland, men det er fremdeles ikke innført et slikt tilbud til de unge norske helsefagarbeiderne.

De fleste yrkesfaglærerne som underviser på helsearbeiderfagutdanningen har bakgrunn som sykepleiere (Høst et al., 2012, s. 79; Skålholt et al., 2013, s. 29). Yrkesfaglærerens fagbakgrunn kan se ut til å påvirke elevene til å søke seg videre til høyere utdanning i stedet for å fullføre den yrkesfaglige utdanningen. Som en mulig forklaring viser Høst et al. (2012) til at det dominerende faglige forbildet elevene opplever på utdanningen er sykepleier (Høst et al., 2012, s. 80). Dette er i tråd med svenske studier (Eliasson, 2019, s. 82; Eliasson \& Rehn, 2017, s. 46), hvor det også der bekreftes at yrkesfaglærerens fagbakgrunn som regel er sykepleier. Eksemplene lærerne kommer med fra praksisfeltet er da sett fra et høyere hierarkisk nivå enn helsefagarbeidernes, og dermed gitt med et utenforstående blikk (Eliasson, 2019, s. 82). Selv om de samme verdiene gjennomsyrer de ulike yrkesgruppene, ligger det en risiko for reproduksjon av de hierarkiske forholdene som preger helse- og omsorgsfeltet. Dette kan være med på å gi elevene et forbilde til å velge høyere utdanning (Eliasson, 2019, s. 82).

\section{Tidligere forskning og teoretiske perspektiver}

I tidligere forskning av Skålholt et al. (2013, s. 46) stiller yrkesfaglærere som underviser på helsearbeiderfagutdanningen spørsmål ved om det er riktig å legge vekt på at elevene skal bli helsefagarbeidere når de hele tiden har hatt planer om å ta påbygg for å kvalifisere seg for høyere utdanning. Det er et viktig spørsmål lærerne her stiller. Studien viser til lærerens erfaringer med elever som blir irritert av å bli fortalt at de bør bli helsefagarbeidere når det ikke er det de har tenkt 
å bli. Lærerne fremhever helsearbeiderfaget som en fagutdanning, men er tydelige på at utdanningen også kan være en naturlig vei mot høyere utdanning for elevene (Skålholt et al., 2013, s. 46).

I nyere forskning (Johansen, 2020, s. 85) blir det poengtert fra unge nyutdannede helsefagarbeidere at de ønsker en helsefagarbeiderutdanning som er faglig god og tydelig stiller krav til elevene. Det vil ifølge de nyutdannede kunne bidra til å heve statusen på yrket.

Tidligere forskning viser til tre grupper elever blant de som velger påbygg. Den første gruppen ønsker påbygg fordi fagutdanningen inneholder for mye praksis (Markussen \& Gloppen, 2012, s. 12), den andre med bakgrunn i praksiserfaringer fra utdanningen (Johansen, 2020, s. 86; Markussen \& Gloppen, 2012, s. $12)$, og den tredje fordi opplæringen er for teoritung og for lite yrkesrettet i den skolebaserte delen (Høst et al., 2012, s. 82). Disse gruppenes begrunnelser for valg av påbygg står noe i kontrast til hverandre, men viser at det er en del utfordringer og forventninger lærerne skal møte elevene på.

Når elevene først har tatt et aktivt valg av fremtidig yrke, er de tydelige på at opplæringen må oppleves relevant for det yrket de skal utdanne seg til (BødtkerLund et al., 2017, s. 16; Hiim, 2015, s. 145). Elevene trenger å erfare yrket i praksis før de gjør et endelig yrkesvalg (Hiim, 2015, s. 146; Johansen, 2020, s. 86). Kvaliteten på arbeidslivspraksis i YFF-faget er dessuten varierende, og elevene får i mange tilfeller lite oppfølging og dermed et begrenset læringsutbytte (Hiim, 2015, s. 144). Elevene ønsker å bli sett, hørt og tatt på alvor både på læringsbehov og videre utdanningsplaner. Elevene ønsker seg også lærere som er gode og oppdaterte innenfor det yrkesfaget de ønsker å utdanne seg til. I tillegg verdsetter elevene et klasse-/læringsmiljø som er trygt og godt (Bødtker-Lund et al., 2017, s. 16).

Tidligere forskning er i stor grad knyttet til elevenes motivasjon og hvilke faktorer som er viktige eller som påvirker. Det ser ut til å være lite forskning knyttet til hvordan lærerne opplever elevenes variasjon i motivasjon, men noen unntak finnes - jeg vil vise til to studier.

Elevenes manglende motivasjon, og dermed yrkesfaglærerens utfordringer med å skape motivering og interesse for faget hos elevene, er et perspektiv som løftes frem i en svensk studie (Eliasson \& Rehn, 2017). Manglende motivasjon forklares blant annet med helsearbeiderfagets lave status, noe som igjen forklares med kommunenes ansettelser av medarbeidere uten fagutdanning til å utføre de samme arbeidsoppgavene som fagarbeiderne. Dette igjen setter lærerne i forlegenhet; når elevene velger bort yrket underveis, signaliserer de dermed at den kompetansen utdanningen gir ikke verdsettes (Eliasson \& Rehn, 2017, s. 54). En studie av Rokkones og Saur (2016) viser at lærerens valg av faglig og didaktisk fokus og lærerens pedagogiske grunnsyn er med på å forme hvordan lærerne jobber med å motivere elevene og bygge elevenes motivasjon for læring og utvikling (Rokkones \& Saur, 2016, s. 17). Studien viser til at lærere som frigjør seg 
fra målstyring og ytre former for motivasjon, i større grad kan fokusere på eleven og seg selv som fagperson. Dette illustrerer at lærerens rolle er viktig. Min studie bygger videre på dette, og kan være med på å begrunne betydningen av å studere yrkesfaglærerens refleksjoner rundt elever som har et annet formål og grunnlag for sin utdanning enn å bli helsefagarbeider.

\section{Mestring og motivasjonsteoretiske perspektiver}

Motivasjonsteoriene som her er valgt, er gjort med bakgrunn i en forståelse av at motivasjon er noe som skapes, ikke noe som finnes inne i elevene (Katznelson, 2019). Helsearbeiderfagelevene skal motiveres både til den skolebaserte og den praksisbaserte opplæringen. Umotiverte elever er alltid utfordrende for lærerne - motivasjon er sentralt for å utdanne og beholde helsefagarbeidere. Det er her lagt vekt på å få frem ulike aspekter ved motivasjon hos elevene som læreren skal kunne aktivere og utvikle. En av grunnene til at motivasjon er viktig i skolen er at konsekvensen av motivasjon gir læring: "motivation produces" (Ryan \& Deci, 2000, s. 69), og nettopp derfor bør motivering ha en fremtredende betydning for lærere. Motivasjon handler om energi, retning og utholdenhet, som alle er aspekter ved det å komme i gang og utføre det som er intensjonen (Ryan \& Deci, 2000, s. 69).

Selvbestemmelsesteorien innenfor gruppen av ulike motivasjonsteorier handler om menneskers medfødte behov for kompetanse, autonomi og tilhørighet (Deci \& Ryan, 2000, s. 235; Ryan \& Deci, 2000, s. 68). Disse tre behovene blir presentert til å være essensielle eller livsviktige og nødvendige for motivasjon til utvikling og integrering, men også for konstruktiv sosial utvikling og personlig velvære (Deci \& Ryan, 2000, s. 229; Ryan \& Deci, 2000, s. 68). Knyttet til skole og læring viser forskning (Ryan \& Grolnick, 1986, s. 551; Ryan, Stiller \& Lynch, 1994, s. 244) til hvor viktig lærerens omsorg er i forståelsen av å gi elevene emosjonell støtte og trygghet slik at de får mulighet til å være i kontroll, oppleve autonomi og vise engasjement.

Dersom lærerne legger opp til at elevene får en opplevelse av å bli anerkjent og stadig utfordret gjennom de arbeidsoppgavene de deltar i, enten på skolen eller ute i praksis, gir det grunnlag for økt mestringsfølelse, noe som igjen gir grunnlag for utvikling av indre motivasjon og dermed også økt kompetanse (Gagné \& Deci, 2005, s. 553). Dette understøttes også i teori fra blant annet Bandura (1997), som viser til at elevenes indre motivasjon styrkes eller bygges når læreren legger opp til og gir elevene muligheter for opplevelse av mestring (Bandura, 1997, s. 219). Med mindre elevene har tro på at de kan mestre, eller kan forhindre uønskede effekter ved handlingene sine, gir det lite motivasjon til å arbeide eller holde ut i møte med vanskeligheter (Bandura, 2009, s. 179). Derfor blir det ekstra viktig for læreren å gi elevene oppgaver de kan mestre, samtidig som de har noe å strekke seg etter. Det vil i praksis si at oppgavene ikke må være for lette eller for vanskelige, at elevene må oppleve både å bli utfordret og å 
mestre, og dermed beholder eller utvikler de den indre motivasjonen. Banduras teori er også i tråd med Vygotsky (1978, s. 33) sin teori om den proksimale utviklingssonen, som nettopp handler om at utvikling og læring skjer ved at elevene klarer mer, men da sammen med eller ved hjelp av medelever eller lærer. Både teori fra Vygotsky og Bandura tydeliggjør viktigheten av å utfordre elevene nok slik at de stadig lærer mer, men at det skjer best eller mest effektivt sammen med andre. Elevene vil kunne engasjere seg i oppgaver de finner uinteressante, så lenge de forstår meningen og verdien av arbeidet. Alt arbeid læreren legger opp til i opplæringssituasjoner, er ikke nødvendigvis interessante for elevene, men kombinert med mestringsopplevelser vil det kunne være med på å styrke og utvikle den indre motivasjonen (Stone et al., 2009, s. 81).

\section{Praksisfellesskap}

Innledningsvis ble det vist til at en fjerdedel av opplæringen det andre året er lagt til bedrifter via faget yrkesfaglig fordypning (YFF). Teori knyttet til Lave og Wenger (1991/2003, s. 31) sitt begrep praksisfellesskap (community of practice) vil her kunne være med på å gi forståelse til betydningen av praksis. Gjennom faget YFF gis elevene mulighet til å komme inn i et praksisfellesskap. Elevene deltar i en sosial praksis hvor læring er en integrert bestanddel, og læringen skjer i praksisfellesskapet. Praksisfellesskap finnes ifølge Wenger (1998/2004, s. 16) både i skolen og i arbeidslivet. I denne sammenheng brukes begrepet knyttet til praksis i bedrifter som utgjør en stor del av opplæringen til å bli helsefagarbeider. Yrkesfaglæreren kan fungere som en mellommann for opptak til dette fellesskapet (Mårtensson et al., 2019, s. 94). Når læreren fungerer som mellommann, er denne også indirekte med på å sette fortgang i elevenes læringsutbytte i praksis, i forståelsen av at læring skjer nettopp i praksisfellesskapet og ikke bare ved intendert undervisning (Lave \& Wenger, 1991/2003, s. 41). Mårtensson et al. (2019) fremmer også begrepene matchmaker (2019, s. 99), i forståelsen av å være den som kobler riktig praksissted til riktig elev, og firefighter (2019, s. 101), i forståelsen av å være den som rydder opp eller megler mellom elev og praksissted når det er nødvendig, for å beskrive lærerens rolle i elevenes arbeidsplassbaserte praksis.

Forskningsspørsmålene som ble stilt innledningsvis handlet om hvordan yrkesfaglæreren erfarer elever med annet formål og grunnlag for sin utdanning. Det som tydeliggjøres i de presenterte teoriene er en tro på læreren som en mulig signifikant andre, med stor betydning for elevenes utvikling og opprettholdelse av mestringstro og dermed indre motivasjon, samt en mellommann til praksisfellesskapene utenfor skolen. Det handler om den gode lærer som ser elevene, legger til rette for læring, lytter og anerkjenner, men stiller krav etter elevens utgangspunkt og gir elevene trygghet og tro på at de kan mestre. 


\section{Metode}

Formålet med studien er å, i lys av teori og tidligere forskning, diskutere yrkesfaglæreres refleksjoner knyttet til helsearbeiderfagelever som har annet formål og grunnlag for sin utdanning enn å kvalifisere seg til helsefagarbeider.

Forskningstilnærmingen er induktivt, kvalitativt design med intervju som metode (Kvale \& Brinkmann, 2009, s. 35). Intervjuene ble gjennomført som gruppeintervju - til sammen 15 lærere, alle lærere ved helsearbeiderfagutdanningen, fordelt på seks grupper i tre fylker og fem videregående skoler. Alle lærerne er kvinner, noe som også gjenspeiler dominansen av kvinner innenfor helse- og omsorgsyrkene de utdanner til.

Begrunnelsen for å bruke gruppeintervju lå i forståelsen av at kvalitativt intervju i grupper åpner for samspill mellom informantene der de får mulighet til å utdype hverandres erfaringer og meninger (Malterud, 2013, s. 18). I tillegg gir metoden mulighet til at oppfatninger og meninger kan diskuteres. Den sosiale erfaringen antas å øke forståelsen og validiteten av funn fordi ulike perspektiver blir diskutert i gruppene (Patton, 2015, s. 475). Målet var å få gode data i en kontekst der deltakerne kunne vurdere egne synspunkter opp mot de andres, selv om det ikke var et poeng at de skulle komme frem til enighet (Patton, 2015, s. 475) eller at de skulle komme frem med løsninger (Kvale \& Brinkmann, 2009, s. 162).

Svakheten med gruppeintervju er blant annet at den enkelte deltaker får mindre tid i et gruppeintervju (Thagaard, 2013, s. 99), men styrkene er deltakernes mulighet for diskusjon og dialog med hverandre, og dermed muligheten til å påvirke intervjuet underveis gjennom dialogen.

Utvalget av deltakere til gruppeintervjuet er gjort med bakgrunn i en kriteriebasert utvelgelse (Dalen, 2011, s. 49). Kriteriene de ble valgt etter var at de var ansatt som yrkesfaglærere i videregående skole og underviste en ordinær klasse (ikke voksenopplæring) i helsearbeiderfaget. Den første kontakten med skolene tok jeg gjennom tidligere studenter. Når kontakten var opprettet og de var positive til å bidra, avklarte jeg med avdelingsleder ved den enkelte skole. Gruppene ble opprettet ved at den læreren jeg i første omgang hadde kontaktet, videre kontaktet kollegaer etter de gitte kriteriene, slik at det ble en snøballeffekt (Patton, 2015, s. 298). Det ble etter hvert noe frafall, men til sammen deltok 15 lærere i seks grupper. Jeg hadde i utgangspunktet et ønske om grupper på tre-fire deltakere. Jeg end te opp med fire grupper med to personer, en gruppe med tre personer og en gruppe med fire personer. Åtte av de 15 lærerne har bakgrunn som hjelpepleiere/helsefagarbeidere, syv er utdannet sykepleiere. De har til sammen 1-13 års erfaring fra undervisning ved helsearbeiderfaget, noe som tilsvarer i gjennomsnitt 4,7 år. De få som hadde kun ett års erfaring fra utdanning av helsefagarbeidere hadde flere års erfaring fra undervisning på det første generelle nivået (Vg1) innen helse og oppvekst, slik at de alle må kunne sies å være erfarne lærere. 
Intervjuene foregikk på lærernes respektive skoler. De fikk selv bestemme dato og tidspunkt for oppstart. De ble bedt om å sette av 90 minutter totalt. I intervjuene ble det tatt utgangspunkt $\mathrm{i}$ en felles semistrukturert intervjuguide (Kvale \& Brinkmann, 2009, s. 143), som tok sikte på å belyse ulike sider ved lærernes betraktninger rundt elevene på helsearbeiderfagutdanningen. Det ble fokusert spesielt på lærernes opplevelse av elevenes engasjement i klasserommet og deres refleksjoner rundt elevenes kommentarer og refleksjoner knyttet til opplæringen i klasserommet samt i møte med praksisfeltet. De ble også bedt om å knytte refleksjonene opp til elevenes videre utdanningsvalg.

Gruppeintervjuene ble gjennomført, tatt opp på lydfil og transkribert av forfatter, noe som ga nærhet til materialet (Brinkmann \& Tanggaard, 2012, s. 34). Det ble valgt en enkel transkripsjonsstrategi (s. 34), der det avgjørende var å få frem meningsinnholdet i det som var sagt - toneleie eller stemmevolum ble ikke vektlagt. Intervjuene varte i snitt rundt 70 minutter. For å sikre validiteten i studien ble de transkriberte tekstene sendt til deltakerne med mulighet til å kommentere teksten. De som svarte ga sitt samtykke til at teksten sto i forhold til de gruppeintervjuene de hadde vært med på.

Deltakerne ga sitt samtykke til deltakelse etter gjeldende regler, og studien er meldt inn til og godkjent av Norsk senter for forskningsdata (NSD) med referansenummer 337638 .

\section{Analyse}

Ved selv å ha foretatt intervjuene, hadde jeg allerede en viss kjennskap til materialet før arbeidet med å transkribere opptakene startet. I og med at jeg har lang erfaring både som lærer i videregående opplæring og som utdanner av yrkesfaglærere i helse- og oppvekstfag, har jeg også en førforståelse som er med på å prege analysearbeidet. I analysen av gruppeintervjuene er det gjort en meningsfortetting (Kvale \& Brinkmann, 2009, s. 212) av det transkriberte materialet for å utvikle de sentrale temaene. Det er gjennomført en induktiv (Patton, 2015, s. 541) tematisk analyse (Braun \& Clarke, 2006; Clarke \& Braun, 2014) gjennom seks trinn.

I trinn én ble det transkriberte materialet lest gjennom en første gang, samtidig som refleksjoner og spørsmål ble notert underveis. Trinn to handlet om å fremheve og sette ord på viktige poenger knyttet til hovedspørsmålet for studien. Til dette trinnet ble det brukt markeringstusjer manuelt for å fremheve viktige ord og poenger i teksten, og tekstutdrag ble omgjort til koder. Trinn tre startet med kategorisering av kodene, noe som ga temaene. Temaene ble opprettet med bakgrunn i hvordan lærerne beskrev og reflekterte rundt deres møte med elever både i klasserommet og ute i praksis. Mer konkret ble det registrert mønstre i gruppesamtalene på tvers av gruppene, og det var disse mønstrene som ga temaene. Et slikt mønster inneholder nødvendigvis ikke kvoteringer fra alle gruppene i resultatbeskrivelsen under. Selve kategoriseringen ble gjort ved hjelp av 
en tabell i et tekstdokument. Deretter startet trinn fire, som besto av å sjekke ut om temaene fungerte i tråd med de kodede utdragene, men også hele datasettet. Trinn fem var å definere og klargjøre endelige navn på temaene, som ble Utdanning til helsearbeiderfaget? og Elever som velger bort fagutdanning. Siste og sjette trinn var å rapportere temaene og innholdet i disse slik de blir presentert i resultatdelen under. Dette ga også en siste mulighet til å stramme analysen gjennom å velge ut sitater som på den ene siden tydeliggjør de ulike temaene og på den ander er med på å gi svar på forskningsspørsmålet (Braun \& Clarke, 2006, s. 93).

\section{Presentasjon av resultatene}

Problemstillingene omhandler yrkesfaglærerens refleksjoner rundt utdanning av elever til helsearbeiderfaget. Presentasjonen av resultatene er strukturert i form av temaer, noe som er vanlig ved tematisk analyse (Clarke \& Braun, 2014, s. 1948). Resultatene generelt viser til elever som før de starter eller underveis i utdanningen blir klar over at de ikke ønsker å utdanne seg til helsefagarbeider. Mange vet ikke hva de vil med utdanningen. I all hovedsak viser resultatene til de elevene som ender opp med å søke påbygging med ønske om å oppnå studiekompetanse og gå videre til høyere utdanning.

\section{Utdanning til helsearbeiderfaget?}

Det første temaet handler blant annet om hvor mye lærerne vektlegger det å motivere generelt til aktivitet i opplæringen, både i klasserommet og i praksis, samt de forventningene lærerne opplever at elevene møter skolen med.

Lærerne er tydelige på at de bruker mye tid på samtaler med elevene, både for å gi elevene generell informasjon om videre muligheter, men ikke minst for å motivere. Det kan handle om å motivere til generell aktivitet $\mathrm{i}$ klasserommet og det å delta i de læringsaktivitetene lærerne legger opp til. Dette sitatet beskriver en utfordring: "... mange elever som ikke helt veit hva de vil [...] de blir sånne forstyrrende elementer fordi de ikke helt veit hva de vil" (Informantgruppe 2).

Det kan se ut til at lærerne opplever en del av elevene som både problematisk å få engasjert i timen, men også i praksis. Når begrunnelsen er at de ikke skal bli helsefagarbeidere, eller i det hele tatt jobbe innen helsefeltet, er det vanskelig for lærerne å motivere til læringsaktiviteter. En lærer forklarer det slik:

\footnotetext{
Vi prøver jo å yrkesrette inn mot flere yrker også i forhold til hva elevene skal bli og relaterer det til stoff som man også kan bruke utenom, selv om du ikke skal bli sykepleier for eksempel. Så handler det også litt om hvordan vi formilder når du lærer førstehjelp da - hvordan kan du bruke førstehjelp andre steder enn i yrket og det tror jeg elevene oppfatter ganske kjapt. Ja, vi tar det litt sånn generelt. Det handler litt om at man skal favne så mange, du skal jo prøve å fange de som ikke skal ut i læra også. (Informantgruppe 2)
} 
Yrkesfaglærerens paradoks: Utdanne til fagarbeid eller videre studier?

Dette utsagnet kan vitne om at læreren prøver å finne en løsning som skal ivareta alle elevenes læring - enten de skal bli fagarbeidere eller noe helt annet. Lærerne velger en generell tilnærming til fagstoff, slik at alle elevene kan relatere det til ønsket yrke, ikke noe for helsefagarbeideren spesielt. Siden mange av de yrkene elevene sikter seg inn mot krever påbygging til studiespesialisering, fører det også til at læreren må jobbe ekstra for å motivere elevene, slik utsagnet under viser til:

En motivator for at elevene skal eller må holde fokus, er at det er innmari pågang på påbygg her hos oss og elevene må ha et høyt snitt, så de må skjerpe seg og få en femmer for å komme inn. Samtidig så har vi på en måte - det er klart vi er innom ting de ikke syns er så interessant, men da må vi på en måte bare si her er det slik at mesteparten skal bli helsefagarbeidere. Det er der fokuset ligger og skal ligge. (Informantgruppe 6)

En del av motiveringen handler også om å ta opp kritikken av yrkesgruppen eller fagområdet generelt i samfunnet: "... det er hele tiden kritikk til yrket og det er vanskelig å skape yrkesstolthet når det kritiseres alle veier, hele tiden" (Informantgruppe 4).

Ett moment som kommer frem i intervjuene, er de forventningene elevene møter skolen med - en antagelse om at det å velge yrkesfag gir skoledager med mindre faglige anstrengelser og at helse- og oppvekstfag er en lett løsning til videre utdanning. Dette sitatet viser til slik erfaring hos en informantgruppe:

De fleste blir litt overrasket over alt de må kunne, sånn at de får litt sjokk, de tenker nok at yrkesfag er litt billig reise liksom, at de kanskje har tenkt litt sånn, selv om de kanskje har gode karakterer og sånn så syns de nok at det har vært litt krevende. (Informantgruppe 3)

Ellers påpeker flere informantgrupper at de har tydelige krav overfor elevene til å bidra i de læringsaktivitetene det legges opp til samt at de holder et høyt faglig nivå, noe dette sitatet viser til:

Vi har nok et veldig faglig fokus. Fort i gang med fag og lite dilldall! Vi har ikke dilldall på Vg2 altså. Hele tiden - vi må skryte litt av det - jeg tror vi hele tiden er flinke til å hele tiden å la elevene spørre: Hvorfor skal jeg kunne det her?

(Informantgruppe 3)

\section{Elever som velger bort fagutdanning}

Det andre temaet beskriver lærerens mer konkrete erfaringer med den sammensatte gruppen elever som velger seg bort fra en fagutdanning samt hvordan elevenes valg påvirker lærerne.

En del av de elevene som i utgangspunktet har planer om å utdanne seg til helsefagarbeider, ender opp med å søke seg rett til påbygg etter at den skolebaserte opplæringen av utdanningen er ferdig. Dette handler ifølge lærerne blant annet om hvordan elevene blir møtt og ivaretatt av veilederne i praksis. I tillegg trekker lærerne også frem at dersom en arbeidsplass har mange assistenter, 
påvirker det yrkesstoltheten og gjør at den kommer i tvil, noe dette utsagnet bekrefter:

\begin{abstract}
De som ofte blir usikre opp gjennom året, er de som ofte søker påbygg. I starten kan mange si at de skal gå lærling og to år og så ta fagbrev og så pábygg, men så gjør de ikke det likevel [...] hvordan de har blitt møtt og ivaretatt i praksis av veiledere har mye å si. Og så er det det med ufaglærte ute i praksis som gjør at yrkesstoltheten forsvinner litt og det er noen ganger de som også er veiledere som kanskje ikke kan faget godt nok, det blir nesten eleven som kan mer, de kan rutinene og det praktiske, men så klarer de ikke begrunne og det er den begrunnelsen vi fokuserer mye på. (Informantgruppe 4)
\end{abstract}

Læreren viser her til en forståelse for forskjellen på en assistent og en fagarbeider, der fagarbeideren må kunne begrunne og vise forståelse for det de gjør, noe det ikke nødvendigvis forventes at en assistent uten fagarbeiderkompetanse skal kunne. I tillegg vises det her til veiledere uten formell kompetanse.

Gjennom tidligere elever viser lærerne til at mange av elevene som søker seg til påbygg ikke er forberedt på hva som møter dem der. Elevene opplever det som tøft, både i forhold til faglig nivå og studierutiner - "de er like lite forberedt på det som de var på det å komme inn på helsearbeiderfaget" (Informantgruppe 4). Flere lærere er også bekymret for at elevene ender opp uten en utdanning når de velger å gå videre til påbygg, noe dette sitatet viser til:

\begin{abstract}
Mange er umodne om det er lov å si det, mange som ikke har erfaringen og vi har sett det år etter år hva som skjer. Jeg tror en veldig viktig ting er det med de som skal søke påbygg tredje året for å søke sykepleien, det er veldig fint det også, men det de ikke tenker på er at karakteren faller veldig ofte på påbygg, og det da blir et snitt som du da ikke kommer inn med på sykepleien [...] og det de ikke forstår er når du søker deg inn med et snitt på tre for eksempel så kan det falle enda mer, og hvor er det du kommer inn i dag med et snitt på tre på høyere utdanning? Det er jo nesten ingen steder. Dette får de informasjon om tidlig. (Informantgruppe 4)
\end{abstract}

I tillegg til de to gruppene som velger bort fagutdanningen, som har eller i løpet av skoleåret får annet formål med utdanningen, har vi en gruppe som har et klart mål fra oppstarten av utdanningen: De skal bli sykepleiere. Lærerne, hvorav åtte er fagarbeidere og syv er sykepleiere, synes ikke å være bekymret eller ha spesielle utfordringer med denne gruppen. Disse utsagnene bekrefter dette:

De jobber godt, er målbevisst og er mer klar til å brette opp ermene, mer reflekterte over egne ressurser og egen væremåte, litt større innsikt i hva som kreves og hva de tenker om fremtiden. (Informantgruppe 1)

De som sitter og veit de vil bli sykepleiere føler det like relevant som dem som skal bli helsefagarbeidere. [...] de begynner på sykehjem de også, og det med observasjonsbiten og de praktiske ferdighetene det har vi hatt fokus på da de som skal på sykepleien vil da ha et veldig godt utgangspunkt. Vi tror også at det motiverer dem. (Informantgruppe 4)

I tillegg opplever lærerne elevene som er tydelige på at de skal bli helsefagarbeidere som mer modne. Det kan da stilles spørsmål ved om motivasjon har noe med modenhet å gjøre, eller om de elevene som læreren opplever som modne er 
Yrkesfaglærerens paradoks: Utdanne til fagarbeid eller videre studier?

der som lærerne finner eller kjenner igjen noe motivasjon for yrket. Dette sitatet kan være med på å understøtte denne argumentasjonen:

Mer modne enn de andre, mer tydelige, mer klar til å ta i et tak og brette opp ermene. Ikke bare, men, det som skiller de er, jeg syns de er mer reflekterte over egne ressurser og egen væremåte, de som velger fagbrev. (Informantgruppe 1)

De ulike informantgruppene er forholdsvis enige om at det kan være til dels tungt å jobbe med og mye uro i klasser der mange velger påbygg. Det kan bli mye forstyrrelser og støy fordi en stor del av elevene ikke vet hva de vil bli, de bare er der. De viser ikke interesse for faget og føler ikke noe tilknytning til utdanningen. Det er vanskelig å få dem til å være med på det som skal gjennomføres, og det er utfordrende for lærerne å dekke alle de ulike behovene de enkelte elevene har. Lærerne uttrykker at de har en forståelse for at elevene vil sikre seg studiekompetanse, men at de likevel ikke legger spesielt til rette for de som uttrykker at de skal velge påbygg. Følgende utsagn viser til noen av disse utfordringene:

\begin{abstract}
De som lager uro, de er ikke motivert og de kjeder seg. Da burde de vært veiledet bort for lenge siden fra helsefag. Men să er mulighetene der da, og det er utfordringen vår - muligheten er der så oppi dagen at du kan bruke dette som et springbrett til påbygg og jeg har ikke noen myndighet til å fortelle hva de skal gjøre. (Informantgruppe 2)

Skal bare sikre seg den studiekompetansen, og er veldig ærlige på at de tenkte det var en lett vei til studiekompetanse. Og de var i utgangspunktet litt teorileie når de søkte seg inn på Vg1, så da valgte de yrkesfag. (Informantgruppe 1)

Det er mange elever som ikke helt veit hva de vil [...] de blir sånne forstyrrende elementer fordi de ikke helt veit hva de vil. De er bare der, vil veldig gjerne på påbygg, men vet ikke hva de skal etterpå, føler ikke noe tilknytning og noe interesse for faget, så det er vanskelig å få de til å være med, og så blir gruppa da veldig splitta. Det opplever jeg nå i vår gruppe og jeg har opplevd det før. Så jeg syns det kan være litt vanskelig å dekke alle behovene rett og slett. (Informantgruppe 2)
\end{abstract}

Det siste utsagnet viser at det er utfordrende for lærerne å nå alle de ulike mål og ønsker elevene her. Ser vi noe mer på hvordan læreren møter disse utfordringene, handler det blant annet om at de legger opp til at elevene skal oppleve å mestre - "det handler om mestring" (Informantgruppe 5). Hvordan lærerne går frem for at elevene skal oppleve mestring blir tydeliggjort ved at lærerne er opptatt av å gi støtte til elever i praksis, og viser til noen gode erfaringer med de elevene som ikke finner seg til rette og som i større grad trenger lærerens støtte for å føle trygghet - noe dette sitat viser til:

Jeg tenker at det er ting som vi har et stort ansvar for å ta tak i og lytte til for eksempel om det er en elev som opplever å ikke bli ivaretatt og som ikke sier det så tydelig, noe som også kjennetegner den alderen og som vi må vite om og forstå da det ikke kommer så tydelig frem, men da er det en måte å gjøre det på er å gå litt foran og ta kontakt med den veilederen og prøve å legge til rette for en bedre læringssituasjon i praksis og vi vet jo det at det å være trygg, det å ha en som går tett 
inntil og viser deg, så det er masse ting vi kan gjøre egentlig. Og jeg syns oftest det fører frem. (Informantgruppe 4)

Denne læreren viser også til at hun "går tett inntil", i likhet med flere lærere i informantgruppene som fremhever at de aktivt går inn i praksis og følger opp elever. Det kan være i form av samtaler med elevene i praksis eller hjelpe til med de oppgavene elevene er satt til av arbeidstedet. Sitatet som følger er et eksempel: "Vi gjør forskjellige prosedyrer og arbeidsoppgaver sammen med elevene og reflekterer rundt det, og det blir da mer konkret for dem" (Informantgruppe 4).

Utsagnene under fra to lærergrupper summerer opp mye av det som kom frem i lærernes refleksjoner: De respekterer elevenes valg av utdanning, de bryr seg om elevene og vil legge til rette for at alle skal få en god utdanning og læring, men de forholder seg til kompetansemålene for utdanningen og krever at elevene jobber aktivt. Samtidig tydeliggjør de også praksis som en viktig del av opplæringen i helsearbeiderfaget.

\footnotetext{
Jeg tenker over og viser interesse for hva elevene velger, men undervisningen styres ut fra kompetansemålene. Vi har et høyt faglig trykk hele tiden, hvorfor skal de kunne dette, knytter teorien til praksis. (Informantgruppe 2)

Jeg er opptatt av at elevene gjør gode og riktige valg for seg selv, jeg kan vise vei og gi de et bilde av hva det handler om, men de kan oppleve mye ute i praksis, hva yrket handler om, men det er bare en liten del av det. (Informantgruppe 4)

Ellers må jeg jo si at det ikke er vanskelig å forstå at det blir veldig abstrakt og det kan endatil ta litt av motivasjonen fra de fleste. Så det prøver vi på alle mulige måter å legge til rette for at det er en sammenheng mellom teori og praksis. For det vet vi jo øker jo motivasjonen og læringen. Så igjen så er det viktig med praksis. (Informantgruppe 4)
}

\section{Oppsummering av resultater}

Det er en sammensatt gruppe elever lærerne presenterer i sine refleksjoner. Blant annet beskriver lærerne elever som i stor grad ikke vet hva de vil med utdanningen samt elever som underveis i skoleåret møter praksis og blir usikre. Lærerne ender da opp med å legge til rette for en noe mer generell fremstilling av fagstoffet, slik at de skal favne alle elevenes ulike grunnlag og mål med utdanningen.

Det er enighet blant flere informantgrupper at en stor del av arbeidet deres går ut på å motivere elevene til å gjøre en innsats både i klasserommet og ute i praksis. Det er også en felles forståelse for at elevenes møte med praksis har mye å si for både læring og valget de tar til enten å bli fagarbeidere eller å gå videre til påbygg. Lærerne har også en forståelse av at de betyr mye for elevene i praksis. Læreren opplever en del elever som umotiverte, og det gir noen utfordringer for lærerne når de skal følge opp i praksis. Læreren har et ansvar overfor elevene at de blir innlemmet i praksis og slik får en mulighet til å lære. Videre opplever de et ansvar overfor skolen, der planer skal følges og alle elevene skal ut i praksis. Slik opplever læreren at de er bindeleddet mellom den enkelte elev, skolen og 
Yrkesfaglærerens paradoks: Utdanne til fagarbeid eller videre studier?

praksisbedriften. Dette trekantansvaret vurderer lærerne som utfordrende, spesielt med en stor gruppe umotiverte elever og med varierende kvalitet på veiledningen.

\section{Diskusjon}

Hovedfunnene diskuteres opp mot teorigrunnlaget, tidligere forskning og forskningsspørsmålet: Hvilke refleksjoner har yrkesfaglærerne knyttet til utdanning av elever som har et annet formål og grunnlag for sin utdanning enn å kvalifisere seg til helsefagarbeider?

\section{Yrkets status i utdanningen}

Ifølge Høst og Larsen (2018, s. 128) kan elevenes mulighet til å søke seg videre til høyere utdanning i stedet for å gjøre ferdig fagutdanningen være med på å øke utdanningens status. Det kan tenkes å være med på å øke statusen på helse- og oppvekstfagutdanningen, men på den andre siden kan det også tenkes at det ikke $ø$ ker statusen for selve yrket helsefagarbeider. Kanskje kan det heller ha motsatt virkning. Resultatene fra studien viser lærere som er tydelige på at de følger kompetansemålene for utdanningen, men samtidig legges undervisningen opp slik at det faglige fokus blir noe generelt. Dette begrunnes med at de som ikke skal bli helsefagarbeidere, også skal finne opplæringen nyttig og interessant. Det kan da tenkes at det dermed signaliseres eller underbygges også i utdanningsløpet at det ikke er "nok" å være helsefagarbeider, i og med at fokuset kan se ut til å dreies noe bort fra selve yrkesutøvelsen til en helsefagarbeider. Som en av lærerne sa: "Det blir veldig abstrakt" (Informantgruppe 4).

Sett opp mot Liedutvalgets klare melding om at hovedformålet til de yrkesfaglige utdanningsprogrammene skal være å utdanne fagarbeidere (NOU 2019:25, s. 92), kan det stilles spørsmål ved denne tilretteleggingen. På den andre siden kan man si at det er prisverdig at læreren støtter opp om elevenes valg og at det finnes en mulighet til å endre kurs underveis - at de ikke er låst i sitt første valg.

Samtidig var informantgruppene opptatt av å stille tydelige faglige krav til elevene og krav om aktiv deltakelse. Men dersom det faglige fokuset er generelt og ikke spesifikt rettet mot helsearbeiderfaget, kan det også være med på å styrke en forståelse for at yrket er mindre viktig. Det kan være forståelig at læreren i forsøk på å nå hele elevgruppens ulike ønsker for videre utdanning legger opp til et generelt faglig innhold i undervisningen. Når elevene ikke viser interesse for helsearbeiderfaget og da heller ikke føler noe tilknytning til utdanningen, kan man forstå lærerne. Spesielt én informantgruppe fremhever dilemmaet i å veilede elevene bort fra utdanningen når hverken grunnlaget eller formålet er til stede. 
Sett opp mot de finske elevenes mulighet til å gå direkte til høyere utdanning etter ferdig utdannet fagarbeider, har vi i Norge et stykke å gå. Lærere i tidligere forskning er også klare på at utdanningen slik den er i dag er en naturlig vei mot høyere utdanning for elevene (Skålholt et al., 2013, s. 46). Mye av det som kommer frem i resultatene fra denne studien, forstås dit hen at læreren til en viss grad lar elevenes videre utdanningsvalg styre det faglige innholdet. Dette kan også være med på å utydeliggjøre utdanningen. Unge nyutdannede helsefagarbeidere poengterer at de ønsker en utdanning som er faglig god og tydelig stiller krav til elevene. Det vil kunne bidra til å heve statusen på yrket (Johansen, 2020, s. 85). Nettopp kvaliteten på utdanningen er lærerne også opptatt av i denne studien de får tydelig frem at de stiller høye faglige krav til elevene. Dette står noe i kontrast til den oppfatningen lærerne sier elevene kommer inn i skolen med, nemlig at det å søke yrkesfag er en "billig reise". Dette kan også sies å være med på å understøtte yrkets status i samfunnet, i tillegg til det faktum at også mange uten formell kompetanse er veiledere i praksis (Informantgruppe 4) og har de samme arbeidsoppgavene som en helsefagarbeider (Eliasson \& Rehn, 2017).

\section{Studieforberedt heller enn yrkesforberedt}

En av grunnene elevene oppgir for å velge høyere utdanning underveis, er at utdanningen til helsefagarbeider oppfattes som for lite yrkesrettet i den skolebaserte delen av opplæringen (Høst et al., 2012, s. 82). Med bakgrunn i resultatene i denne studien kan dette forklares på flere måter, blant annet at lærerne, som også nevnt over, er fleksible i sin tilnærming til fagstoffet og at de legger opp til at elevene skal ha mulighet til å søke seg videre. I tillegg kan det faktum at mange av lærerne er sykepleiere kunne tenkes å påvirke elevene gjennom utdanningen til i noen grad å bli studieforberedt heller enn yrkesforberedt. Slutningen kan også begrunnes ut fra tidligere forskning (Høst et al., 2012), der yrkesfaglærerens fagbakgrunn pekes på å kunne påvirke elevene til å søke seg videre til høyere utdanning i stedet for å fullføre den yrkesfaglige utdanningen fordi det faglige forbildet elevene opplever på utdanningen til helsearbeiderfaget er sykepleier. I tillegg kan det at elevene velger bort yrket underveis signalisere at den kompetansen utdanningen gir, ikke verdsettes (Eliasson \& Rehn, 2017, s. 54). Studien var ikke lagt opp til å få frem om det var noe forskjell på om lærerne var utdannet sykepleier eller hadde bakgrunn som fagarbeider. Uansett var lærerne enige i at de forholdt seg til kompetansemålene i læreplanen, samtidig som de tilrettela fagstoffet for ulike yrker. Dette kan også ses opp mot kritikken om at kompetansemålene for helse- og oppvekstfagene er noe generelle, teoretiske og lite praktiske i sin tilnærming til yrkesutøvelsen som helsefagarbeider. For eksempel er ett av kompetansemålene for andre klasse helsearbeiderfaget at elevene skal "drøfte ulike former for kommunikasjon og gjøre rede for hvordan kommunikasjon kan fremme trygghet og tillit" (Udir.no). 
Yrkesfaglærerens paradoks: Utdanne til fagarbeid eller videre studier?

\section{Bærekraftig motivasjon}

Ut fra teori og tidligere forskning er det mulig å forstå at noen av elevene ikke er motivert for læringsaktiviteter hverken i den skolebaserte delen av opplæringen eller i praksis. Dersom de ikke opplever mestring (Johansen, 2020, s. 86; Markussen \& Gloppen, 2012, s. 12; Stone et al., 2009, s. 81) eller må ha praksis i et yrke de ikke ønsker eller kjenner (Bødtker-Lund et al., 2017, s. 16), samtidig som det i skolen undervises for et yrke mange ikke ønsker seg (Skålholt et al., 2013, s. 46), er det mulig å forstå at elevene ikke klarer å opprette nok indre motivasjon til å fullføre utdannelsen. De mister energi, retning og utholdenhet (Ryan \& Deci, 2000, s. 69). Kanskje det er dette læreren opplever når de i stor grad trekker frem at mye av deres innsats går ut på å motivere elevene til generell deltakelse i læringsaktiviteter. Umotiverte elever er alltid utfordrende for lærerne (Eliasson \& Rehn, 2017, s. 56).

En utfordring for lærerne kan være spørsmålet om hvordan de kan skape autonom eller bærekraftig motivasjon hos elevene og hvordan det kan oppnås til tross for at enkelte oppgaver kanskje ikke er interessante for elevene. Ett svar kan være å utfordre elevene i de arbeidsoppgavene de er med på, og ifølge teorien kan det gi muligheter for mestringsopplevelser som igjen kan gi motivasjon og dermed økt kompetanse (Bandura, 2009, s. 219; Gagné \& Deci, 2005, s. 553).

Intervjuguiden var ikke innrettet på å avdekke i hvilken grad lærerne gir elevene valgmuligheter og ansvar, men lærerne er derimot tydelig på at de stiller krav til elevene. Det understøttes videre i teori både fra Bandura (1997, s. 219), Gagné og Deci (2005, s. 553) samt Vygotsky (1978, s. 33) at det å gi oppgaver som kan mestres, men også stille krav, gir muligheter for økt motivasjon hos elevene. Men, gjennom lærerens betraktninger - dersom elevene ikke er motivert og i liten grad får være med på å bestemme samt føle at det de ønsker blir tatt hensyn til kan det være vanskelig å få til. Slik sett blir lærerens tilnærming til elevenes opplæring her styrket ved at det tas hensyn til elevenes videre yrkesvalg.

\section{Betydningen av praksis i utdanningen}

Praksis blir av lærerne vurdert til å være viktig for elevenes læring og valg av yrke. Tidligere forskning (Hiim, 2015, s. 146; Johansen, 2020, s. 86) tydeliggjør nettopp nødvendigheten av at elevene opplever yrket i praksis før de tar et endelig yrkesvalg. Praksis anses som en betydningsfull, men krevende del av opplæringen slik lærerne vurderer det. Det er også et funn at noen av veilederne er uten formell kompetanse, og det vil da kunne stilles spørsmål ved kravene for å være veileder og hvem det er som godkjenner veilederne. Viktigheten av å ha gode veiledere bekreftes i teori fra Wenger (1998/2004, s. 16), hvor praksis-fellesskapet som elevene blir en del av ute i bedriftene gir elevene en sosial praksis der læringen er en integrert del. Læringen skjer ifølge Wenger i praksisfellesskapet, 
og dermed fordrer det også en kompetent veileder ute i praksis som sammen med læreren viser elevene vei inn i praksisfellesskapet.

Ifølge resultatene opplever lærerne at elevene ønsker og trenger en lærer i praksis for mer trygghet, og dermed mestring (Bandura, 1997), som bygger motivasjon som igjen gir læring. Lærerne synes det er vanskelig å få dekket alle behovene elevene har, men de ser ut til å ha gode erfaringer med å følge opp elevene tett i praksis. Siden praksis er en så stor del av opplæringen til helsearbeiderfaget, og fordi opptak til praksisfellesskapet er viktig for læring i praksis (Lave \& Wenger, 1991/2003, s. 41), er det et viktig poeng lærerne her er opptatt av. De skal ikke bare opptre som en matchmaker eller firefighter (Mårtensson et al., 2019, s. 99 og s. 101), men som en som i større grad aktivt er med, en støtte for elevenes mestring av og i praksis. Lærerne som ifølge studien går ved siden av, trygger, hjelper og jobber sammen med elevene.

Videre kan dette også ses i sammenheng med en svensk studie (Eliasson \& Rehn, 2017, s. 54) som forklarer elevenes manglende motivasjon med yrkets lave status og mange ansatte uten utdanning til å utføre de samme oppgavene som fagarbeidere.

Tidligere forskning (Bødtker-Lund et al., 2017, s. 16) poengterer at elevene vil ha et trygt og godt læringsmiljø og ønsker å bli sett, hørt og bli tatt på alvor. Dette blir også bekreftet i lærerens refleksjoner rundt sin egen tilstedeværelse i praksis. Banduras begrep om mestring som en nødvendig forutsetning for indre motivasjon og læring (Bandura, 1997, s. 174), blir her aktualisert sammen selvbestemmelsesteorien til Deci og Ryan (2000, s. 229; Ryan \& Deci, 2000, s. 68). Dette forklares med at lærerens tilstedeværelse i praksis er med på å gi mestringsopplevelser hos elevene.

I artikkelen har det i all hovedsak vært satt søkelys på utdanningen og hvordan det påvirker yrkesfaglærerne og elevene. Noe av utgangspunktet for denne studien var at det $\mathrm{i}$ tidligere forskning i stor grad er fokusert på hva arbeidsplassene kunne gjøre for å bedre yrkets status, slik som for eksempel å tilby de unge nyutdannede hele stillinger (Skålholt et al., 2013, s. 88; Statistisk sentralbyrå, 2019b, s. 7; Vabø et al., 2019, s. 15). Artikkelen har satt søkelys på å finne løsninger for de elevene som ikke er motiverte for utdanningen ut fra hva yrkesfaglærerne og til dels veilederne kan bidra med for at elevene skal lykkes med utdanningen og fullføre den utdanningen de har startet på.

\section{Avslutning}

Det kan se ut til å være et paradoks at læreren både skal utdanne til helsearbeiderfaget og samtidig legge til rette for alle de elevene som har et annet formål og grunnlag for sin utdanning.

Læreren vurderer tydelig at praksis er viktig for elevenes yrkesvalg, og samtidig ser de seg selv som viktige aktører for elevenes trygghet, trivsel og videre læring i praksis. De har en viktig rolle som mestringsstøtte for elevene i praksis, i 
tillegg til å være matchmaker, firefighter og mellommann til opptak i praksisfellesskapet på arbeidstedet.

Videre vil det kunne være interessant å studere hvordan elevene opplever lærerne som mestringsstøtte knyttet til læring i praksis, samt i hvilken grad støtten er med på å redusere at elevene velger seg bort fra fagutdanningen.

Det er et uttalt stort behov for helsearbeidere i fremtiden (Statistisk sentralbyrå, 2019a). På bakgrunn av en samfunnsmessig nødvendighet vil det være ønskelig å utdanne flere unge helsefagarbeidere for å møte fremtidens behov blant annet innenfor kommunalt helse- og omsorgsarbeid.

\section{Om forfatteren}

Else Marie Johansen er universitetslektor og stipendiat ved OsloMet - Storbyuniversitetet, Fakultet for lærerutdanning og internasjonale studier, hvor hun underviser på bachelorutdanning for yrkesfaglærere i helse- og oppvekstfag samt på lærerspesialistutdanningen for helse- og oppvekstfag. Hun har lang erfaring med undervisning og veiledning fra videregående skole. Hennes forskningsinteresser er yrkesopplæring, med vekt på utdanning innen helse- og oppvekstfagene. 


\section{Referanser}

Bandura, A. (1997). Self-efficacy: The exercise of control. W. H. Freeman and Company.

Bandura, A. (2009). Cultivate self-efficacy for personal and organizational effectiveness. I E. A. Locke (Red.), Handbook of principles of organization behavior (2. utg., s. 179-200). John Wiley \& Sons Ltd.

Braun, V. \& Clarke, V. (2006). Using thematic analysis in psychology. Qualitative Research in Psychology, 3(2), 77-101. https:/ / doi.org/10.1191/1478088706qp063oa

Bødtker-Lund, D., Hansen, K. H., Haaland, G. \& Vagle, I. (2017). Endringsbehov i norsk yrkesopplæring? Elevers, lærlingers og yrkesfaglæreres erfaringer med yrkesopplæring i Vg1. Scandinavian Journal of Vocations in Development, 2, 1133. https://doi.org/10.7577/sjvd.2577

Brinkmann, S. \& Tanggaard, L. (2012). Intervjuet: Samtalen som forskningsmetode. I S. Brinkmann \& L. Tanggaard (Red.), Kvalitative metoder: Empiri og teoriutvikling (s. 17-46, W. Hansen, Overs.). Gyldendal Akademisk.

Clarke, V. \& Braun, V. (2014). Thematic analysis. I T. Teo (Red.), Encyclopedia of critical psychology (s. 1947-1951).

https:/ / doi.org/10.1007/978-1-4614-5583-7_311

Dalen, M. (2011). Intervju som metode: En kvalitativ tilnærming. Universitetsforlaget.

Deci, E. L. \& Ryan, R. M. (2000). The "What" and "Why" of goal pursuits: Human needs and the self-determination of behavior. Psychological Inquiry, 11(4), 227268. https://doi.org/10.1207/s15327965pli1104_01

Eliasson, E. (2019). Att undervisa för utveckling av yrkeskunnande i vård och omsorg. Nordic Journal of Vocational Education and Training, 9(1), 66-88. https:/ / doi.org/10.3384/njvet.2242-458X.1991

Eliasson, E. \& Rehn, H. (2017). Health and social care teachers' descriptions of challenges in their teaching at upper secondary school. Nordic Journal of Vocational Education and Training, 7(1), 42-63.

https:/ / doi.org/10.3384/njvet.2242-458X.17v7i1

Gagné, M. \& Deci, E. L. (2005). Self-determination theory and work motivation. Journal of Organizational Behavior, 26(4), 331-362. https://doi.org/10.1002/job.322

Hiim, H. (2015). Kvalitet i yrkesutdanningen: Resultater fra et aksjonsforskningsprosjekt om yrkesforankring av innholdet i yrkesutdanningen. Norsk pedagogisk tidsskrift, 99(2), 136-148.

Høst, H., Karlsen, H., Skålholt, A. \& Hovdhaugen, E. (2012). Yrkesfagutdanning eller allmennutdanning for sektoren? (NIFU-rapport 30/2012). Nordisk institutt for studier av innovasjon, forskning og utdanning.

https://www.nifu.no/publications/952172/ 
Yrkesfaglærerens paradoks: Utdanne til fagarbeid eller videre studier?

Høst, H. \& Larsen, L. (2018). Vocational education for health care workers in the Nordic countries compared. I C. Helms Jørgensen, O. J. Olsen \& D. Persson Thunquist (Red.), Vocational education in the Nordic countries: Learning from diversity (s. 118-136, Routledge Research in International and Comparative Education, Vol. 2.). Routledge. https://doi.org/10.4324/9781315414492

Johansen, E. M. (2020). Helsefagarbeideren, yrkesfaglæreren og det tredelte klasserommet. Fagbladet Samfunn og økonomi, (1-2), 74-89.

http:/ / www.fagbladet2.com/fagbladet/PDF/samfunnogokonomi/Samfunn_og_okonomi-14.pdf

Katznelson, N. (2019, 6. august). Noemi Katznelson: Vejen til motiverede elever. EMU Danmarks Læringsportal. https:// www.emu.dk/eud/paedagogik-og-didaktik/motivation-og-feedback/noemi-katznelson-vejen-til-motiverede-elever

Kvale, S. \& Brinkmann, S. (2009). Det kvalitative forskningsintervju (2. utg., T. M. Anderssen \& J. Hygge, Overs.). Gyldendal Akademisk.

Lave, J. \& Wenger, E. (2003). Situeret læring og andre tekster (B. Nake, Overs.). Hans Reitzels Forlag. (Opprinnelig utgitt 1991).

Malterud, K. (2013). Kvalitative metoder i medisinsk forskning: En innføring (3. utg.). Universitetsforlaget.

Markussen, E. \& Gloppen, S. K. (2012). Påbygg - et gode eller en nødløsning? En studie av påbygging til generell studiekompetanse $i$ Østfold, Akershus, Buskerud, Rogaland og Nord-Trøndelag skoleåret 2010-2011 (NIFU-rapport 2/2012). Nordisk institutt for studier av innovasjon, forskning og utdanning. https:/ / nifu.brage.unit.no/nifu-xmlui/bit-

stream/handle/11250/280848/NIFUrapport2012-2.pdf?sequence=1\&isAllowed $=\mathrm{y}$

Mårtensson, Å., Andersson, P. \& Nyström, S. (2019). A recruiter, a matchmaker, a firefighter: Swedish vocational teachers' relational work. Nordic Journal of Vocational Education and Training, 9(1), 89-110.

https:/ / doi.org/10.3384/njvet.2242-458X.199189

NOU 2019:25. (2019). Med rett til å mestre: Struktur og innhold i videregående opplæring. Kunnskapsdepartementet. https:/ / www.regjeringen.no/contentassets/2c79526bf80444b7ba90d1f22e52530b/no/pdfs/nou201920190025000d ddpdfs.pdf

Niittylahti, S., Annala, J. \& Mäkinen, M. (2019). Student engagement at beginning of vocational studies. Nordic Journal of Vocational Education and Training, 9(1), 21-42. https:/ / doi.org/10.3384/njvet.2242-458X.199121

Patton, M. Q. (2015). Qualitative research \& evaluation methods: Integrating theory and practice (4. utg.). SAGE.

Rokkones, K. L. \& Saur, E. (2016). Yrkesutdanning for elever som står i fare for å slutte - en studie av et alternativt opplæringsprosjekt. Skandinavisk tidsskrift for yrker og profesjoner i utvikling, 1, 1-20. https://doi.org/10.7577/sjvd.1795 
Ryan, R. M. \& Deci, E. L. (2000). Self-determination theory and the facilitation of intrinsic motivation, social development, and well-being. American Psychologist, 55(1), 68-78. https:// doi.org/10.1037//0003-066X.55.1.68

Ryan, R. M. \& Grolnick, W. S. (1986). Origins and pawns in the classroom: Selfreport and projective assessments of individual difference in children`s perceptions. Journal of personality and Social Psychology, 50(3), 550-558. http:/ / selfdeterminationtheory.org/SDT/documents/1986_RyanGrolnick_JPSP.pdf, https:/ / doi.org/10.1037/0022-3514.50.3.550

Ryan, R. M., Stiller, J. D. \& Lynch, J. H. (1994). Representations of relationships to teachers, parents, and friends as predictors of academic motivation and self-esteem. The Journal of Early Adolescence, 14(2), 226-249. https:/ / doi.org/10.1177\%2F027243169401400207

Sandal, A. K. \& Smith, K. (2012). Møte med yrkesfagleg utdanning i den norske videregåande skulen. Nordic Journal of Vocational Education and Training, 2(1), 1-17. https://doi.org/10.3384/njvet.2242-458X.12v2i1

Skålholt, A., Høst, H., Nyen, T. \& Tønder, A. H. (2013). Å bli helsefagarbeider: En kvalitativ undersøkelse av overganger mellom skole og læretid, og mellom læretid og arbeidsliv blant ungdom i helsearbeiderfaget (NIFU-rapport 2013-5). Nordisk institutt for studier av innovasjon, forskning og utdanning. https:/ / www.nifu.no/publications/1007037/

Statistisk sentralbyrå. (2019a). Arbeidsmarkedet for helsepersonell fram mot 2035 (Rapporter 2019/11). https:/ / www.ssb.no/arbeid-og-lonn/artikler-og-publikasjoner/_attachment/385822?_ts=16a9632c1f0

Statistisk sentralbyrå. (2019b). Helsefagarbeidernes arbeidssted og nyutdannede helsefagarbeideres tilknytning til arbeidslivet (Rapporter 2019/20).

https://www.ssb.no/helse/artikler-og-publikasjoner/_attachment/391417?_ts=16badab6b88

Stone, D. N., Deci, E. L. \& Ryan, R. M. (2009). Beyond talk: Creating autonomous motivation through self-determination theory. Journal of General Management, 34(3), 75-91. https:/ / doi.org/10.1177\%2F030630700903400305

Tarrou, A.-L. H. \& Johannesen, H. S. (2010). Perspektiver på kunnskapssyn ved læring i yrkesfag-opplæringen. I B. Aamotsbakken (Red.), Læring og medvirkning (s. 93-107). Universitetsforlaget.

Thagaard, T. (2013). Systematikk og innlevelse: En innføring i kvalitativ metode (4. utg.). Fagbokforlaget.

Utdanningsdirektoratet. (2016). Yrkesfaglig fordypning for de yrkesfaglige utdanningsprogrammene (YFF). Direktoratet. https:/ / www.udir.no/laring-og-trivsel/lareplanverket/finn-lareplan/yrkesfaglig-fordypning/

Utdanningsdirektoratet. (2020). Fag-og timefordeling og tilbudsstruktur for Kunnskapsløftet. https://www.udir.no/regelverkstolkninger/opplaring/Innholdi-opplaringen/udir-1-2020/ 
Yrkesfaglærerens paradoks: Utdanne til fagarbeid eller videre studier?

Utdanningsdirektoratet. (u.å.). Programområde for helsearbeiderfag: Læreplan i felles programfag Vg2 (HEA2-03). https:/ / www.udir.no/k106/HEA203/Hele/Kompetansemaal/kommunikasjon-og-samhandling

Vabø, M., Drange, I. \& Amble, N. (2019). Den vanskelige deltidsknuten: En særnorsk utfordring som rammer unge helsefagarbeidere. Fagbladet Samfunn og økonomi, (1-2), 6-21. https:/ / fagbladet.no/mapper/dokumenter/Deltidsknuten_siste.pdf

Vygotsky, L. S. (1978). Interaction between learning and development. I M. Cole, V. John-Steiner, S. Scribner \& E. Souberman (Red.), Mind and society: The development of higher psychological processes (s. 79-91). Harvard University Press.

Wenger, E. (2004). Praksisfellesskaber: Læring, mening og identitet. (B. Nake, Overs.). Hans Reitzels Forlag. (Opprinnelig utgitt 1998). 